\title{
Henry James ex Cathedra: The Performing Pedagog
}

\section{Thor Gabrielsen}

Sagene College of Education, Oslo

At a time when Henry James began seriously to worry about the steadily shrinking circle of his readership, he made, in a letter to William Dean Howells of January 2nd, 1888, a for him unusually bold and sanguine prediction, 'Very likely too, some day, all my buried prose will kick off its various tombstones at once."1

Twenty years later, when the demand for James's fiction was at its lowest ebb, we find him hard at work to hasten the process of removing the slabs from the tomb of his literary oeuvres. This was to be done by preparing a selectively collected Definitive Edition of all his fiction in 24-later 26-volumes, later to be referred to as the New York Edition (NYE). For this he wrote a series of eighteen Prefaces about which he writes to Grace Norton on March 5th, 1907,

the real tussle is in writing the Prefaces [which are] difficult to do-but I have found them of jolly interest; and though I am not going to let you read one of the fictions themselves over I shall expect you to read all the said Introductions. ${ }^{2}$

To Howells, the following year, James more explicitly states the over-all purpose of the Prefaces,

My actual attitude about the Lucubrations is almost only ... that they make, to me, for weariness ... This ... blocks out for the hour every aspect but their being all done, and of their perhaps helping the Edition to sell. ... They will have represented much labour to this end - though in that they will have differed indeed from no other of their fellow manifestations. ...

But, James continues, the motive wasn't only a monetary one,

They are, in general, a sort of plea for Criticism, for Discrimination, for Appreciation on other than infantile lines-as against the so almost universal absence of these things. ... They ought, collected together, none the less, to form a sort of comprehensive manual or vademecum for aspirants in our arduous profession. ${ }^{3}$ 
The New York Edition sold rather poorly. And while James's stature and reputation grew into almost formidable proportions among discerning critics and impressed fellow artists, the general reading public continued to neglect him. Only about thirty years after his death were his Prefaces collected and published with a brilliant Introduction by R. P. Blackmur. ${ }^{4}$ They have since come to be recognized as perhaps the most important treatment ever attempted of the philosophy and poetics of the art of prose fiction.

About the Prefaces, James makes four key-points in the letters quoted above. They are 'heavy,' he admits, and have been 'difficult' to do, but the labor has been of 'jolly interest,' he tells Grace Norton. To Howells he expresses the hope that they may serve as a useful and 'comprehensive manual' for aspiring writers.

Taking the fourth point for our theme, we may consider the Prefaces as a series of essays - of 'lectures,' even - with an instructional bias, on the art of fiction, based upon James's own experience, theories and practice.

In the exposition and analysis of his vast material, James brilliantly demonstrates his firm and masterly grasp on the science and method of applied pedagogics. Delivering, seemingly, his 'lectures' ex tempore, without the aid of either manuscript or notes, he establishes from the outset a direct contact with his audience who can only marvel at the 'lecturer's' prodigious feats of memory.

James does, however, in the course of the Prefaces, and on about seven occasions, make some rather vague and generalized remarks about the invaluable 'note-taking habit.' It was only thirty years later, with the coming to light of his nine surviving Notebooks (NB), ${ }^{5}$ that one realized that James had written his 'Lucubrations' with his Notebooks constantly at his elbow.

Thus the Prefaces are to a large extent simply the Notebooks organized and expanded, developed and elaborated and couched in a style deliberately intended to enhance the readers' enjoyment. The matter on which the Prefaces are structured and as lifted from the Notebooks, contains all the pertinent facts of dates and names and places and occasions, of technical terms and discoveries, speculations and statements about the writer's craft, all of this concerned with the 'illuminatory classification, collocation, juxtaposition and separation' 6 of the works that went into the New York Edition.

James's method of exposition is exemplary and in his argument he avails himself of both the inductive and deductive techniques. 
From a number of quoted and meticulously noted cases firm conclusions are logically drawn; upon generally stated principles or observations follow specific examples, these always presented with exact references and vivid illustrations. Where the problem under consideration is a particularly important or knotty one, the main points of the argument will be driven home through relentless though never tedious repetition. Again and again a subject formerly treated is returned to, for instance the eternally fascinating phenomenon of the 'germ' or mère-idé of a story and the mysterious process through which it develops into full fruition-if James finds occasion to point out a new and fresh aspect which may re-enforce or add to our understanding. Cross-references and interrelations knit each Preface to the whole series stringed together as they are on a thread of consistently applied artistic principles, the whole unified by the imaginative consciousness and the highly characteristic voice and tone of the author.

As all good lecturers know, to have a little of the actor in you can be of great advantage in that the histrionic gift has always served as a useful aid to effective communication. Henry James deliberately exploits it to this end. There is a great deal of showmanship in the Prefaces where he gives considerable vent to his almost Gallic sense of humor which is invariably expressed in the ironic and serio-comic vein. He affects, in his relationship with his readers and audience, the tone of intimacy, of confidential conversation, and if his approach may sometimes be a little on the avuncular side, he is never condescending.

Establishing from the outset a you-me relationship, James addresses his interlocutor directly leaving us both free intelligently and urbanely to discuss all sorts of fascinating topics on an equal footing, to state, explain and clarify the questions in such a way that, by a joint effort, we finally seem able to solve them or, at the very least, to reach some kind of gentleman's agreement about them.

As for the entertainment of his audience, James was ever ready to employ 'the rockets, the Roman candles and Catherine-wheels of a 'pyrotechnical display' (AN 53), which would throw its multi-colored lights of irony, wit and humor over himself, his works and his characters to our great amusement. It is mainly to this end that he makes such an extensive use of metaphor and figures of speech in his Prefaces.

As an instructor, James harbors no great illusions about the intelligence and power of sustained attention on the part of his 
readers and students. Again and again he admonishes and beseeches his audience to remain on the alert in order that we become active participants in the creative process of unfolding and developing his theme: 'Attention of perusal . .. is what I at every point ... absolutely invoke and take for granted.' Still, time and again he ruefully reminds himself that an artist can, at best, only benefit from 'his having cast a spell upon the simpler, the very simplest forms of attention' (AN 54). Throughout his writing career, James had been repeatedly struck by the 'So marked collective mistrust of anything like close or analytic appreciation,' of literary works (AN 227) - at least among English readers and critics - and in his more despondent moments he wonders 'whether the very secret of perception hasn't been lost' (AN 229). This passive attitude on the part of readers James had already castigated in his first extensive treatment of 'The Art of Fiction' about twentyfive years earlier where he insinuates that 'Only a short time ago ... there was a comfortable, good-humoured feeling abroad that a novel is a novel, as a pudding is a pudding, and that our only business with it could be to swallow it." 7

On the smallest pretext, James will expatiate on 'the original grossness of readers' (AN 270), even to the point of insulting you, his supposedly distinguished and admirable Preface-reading friend. As happens, for instance, when after having gone into very close quarters with the story of how he conceived of and worked out the very complex idea of 'The Altar of the Dead,' and coming out rather exhausted by the expository struggle, James turns impatiently upon his unsuspecting student with the positively offensive remark, 'in thus engaging my treated theme for the reader's benefit I seem to acknowledge that this more detached witness may not successfully have done so' (AN 247-248).

In general, however, James conducts his tutorial sessions in a very friendly and affable, at times even flattering, manner and saves his occasional sarcasms for those who remain oblivious to his tenets. About himself he can be freely, even frivolously, sardonic.

Henry James refused to acknowledge the artificial distinction made between Reader and Critic. He only insisted that the latter be more responsible and attentive and better informed. Then only might he prove helpful to the artist. Here again James strikes the note of the pedagogical intent of the Prefaces. Discussing, for instance, the vexing problem of 'misplaced middles' which he found to be such a recurrent structural weakness of his larger 
fictions, and using what he calls 'the false and deformed half' of The Wings of the Dove as an illustrative example, he recommends it as 'a signal object-lesson for a literary critic bent on improving his occasion to the profit of the budding artist' (AN 302). However, the critical practice that he observed around him, rarely provided for much enthusiasm on that score.

James liked to consider his Prefaces as all excursion into 'literary history' of a rather special kind. Not that of the academe or the schoolroom, nor that of theories and dogmas, of movements, ideologies and manifestoes. He wasn't unwilling to learn from the practitioners of the 'mot juste' or the 'morceaus de vie' persuasion or from the impressionists. But he never felt at home with the aesthetes of the London intelligentsia or with the bohemians while he found the 'evangelism' of the 'social problem' and the 'l'art pour l'art' devotees equally ridiculous. He might respect Flaubert as an artist and like him as a person, he might admire Maupassant's adroitness and Zola's 'prodigious' effort (AN 31) but he reserved his artistic and personal affection for loners like himself, an Ivan Turgenieff, a Robert Louis Stevenson.

In the Prefaces, 'literary history' meant to James 'the fascinations of the fabulist's art ... the intimate history of the business ... of retracing and reconstructing its steps and stages' (AN 42). He yearned to be able to 'do so subtle, if not so monstrous, a thing as to write the history of the growth of one's imagination' (AN 47). The ambitious striving towards this ideal aim, is what gives to the prefatorial series its accumulative propulsive force as 'the very record and mirror of the general adventure of one's intelligence' (AN 342). The interest in an artist's 'life' is only iegitimate if one contemplates it in the light of and reflection cast by his work.

This doesn't mean that James eschewed the practice and advantages of straight autobiography. His use and application of it constitute, as a matter of fact, one of the main structural elements in the composition of the Prefaces. But he employs it to serve one particular function - again a pedagogical concern - namely to amuse and entertain his audience and, quite unashamedly, himself.

There was, as has already been mentioned, quite a bit of the 'ham' -honni soit! - in James's personal make-up of the kind that one recognizes in the born raconteur. The brilliance of James's conversation has also become a celebrated part of his legend. He loved to cast himself into roles, to don various parts, preferably that of the puzzled and gaping under-dog kind of individual. This he 
most clearly demonstrates in the Prefaces when dealing with his 'untried' artistic youth and where the dominating view of himself is that of a near-failure, an attitude we also recall as characteristic of much of his autobiographical and epistolary writing.

Never is James more indulgently ironic or humorous than when he treats us to the portrait of himself as a young artist. The retrospective view is bathed in the light of romance, and what he calls 'the nostalgic twinge' which sets the tone is called forth by acutely remembered sensual impressions and the memories of the ever changing moods of his Sturm und Drang, of the great ambitions and expectations, of the adventure and anxiety of this 'embarrassed phase' (AN 6). The adventure-however 'mild' James pretends it to have been-of venturing forth into the fancied fairy-tale land of his childhood and youthful reading about the 'Old World' is charged with suspense as he sets out like a progressing pilgrim devoutly prepared to throw himself before the hallowed shrines of accumulated culture and high civilization; or like a dispossessed prince who has returned to claim his birthright, to fight for it and to conquer.

The audience is easily persuaded to accept James's view of his youthful self as that of the 'shy and groping' young aspirant in fiction so filled with 'earnest, baffled intention,' looking and listening with 'so generally gaping a mouth' (AN 6-7). What he most effectively evokes, in this connection, is the acute feeling for and vivid memory of the spirit of place and the human hustle and bustle of the great old cities. These sensual memoranda are, however, always directly linked to his search for the 'germ' of his subject and with his toil and anxiety and joy in developing it. They are the 'contributive facts,' for 'a living work of art, however limited, pretends always, as for parts of its grace, to some good faith of community, however indirect, with its period and place' (AN 213).

Thus justified, James takes you along, back to the Italy of his youth, the first sight of which, in 1869, had given him a 'never-to-be forgotten thrill.' We sit with him in Florence 'in the high, charming, shabby old room' looking out 'through the slite of cooling shutters, at the rather dusty but ever-romantic glare of Piazza Santa Maria Novella' (AN 7), remembering with him how it was 'while the light and the colour and the sound of old Italy played it again at my open windows and about my patient table' (AN 197). Or he will recall, again watching through the windows of his rented 
room, 'the waterside life, the wondrous lagoon spread before me, and the ceaseless human chatter of Venice' (AN 40).

We then journey with him to France, to Paris, looking from his windows into the Rue de Luxembourg and listening to 'the particular light Parisian click of the small cab-horses on the clear asphalt, with its sharpness of detonation between the high houses. ... This sound rises to a martial clatter at the moment a troup of cuirassiers charge down the narrow street. ...'He recalls his

daily effort not to waste time in hanging over the window-bar for a sight of the cavalry the hard music of whose hoofs so directly and thrillingly appealed; an effort that inveterately failed-now dignified by the fact that the fruits of this weakness, the various items of the vivid picture, so constantly recaptured, must have been in themselves suggestive and inspiring, must have been rich strains, in their way, of the great Paris harmony. (AN 26-27)

But James also remembers 'the very odour of Paris which comes up in the rich rumble of Rue de la Paix' and 'the tone of the terrible city' (AN 87). And there are meteorological memories:

A snowstorm of a violence rare in Paris raged ... for many hours, for the greater part of a couple of days; muffling me noiselessly into the small, shiny, shabby salon of an hotel garni with a droll combinational, almost cosmic sign, and promoting ... a deep concentration, an unusual straightness of labour. (AN 213)

From the Kaiser's drilling grounds James recalls

an old inn at Bad-Homburg . ... a dejected and forlorn little place ... a homely enclosure on the ground-level of which I occupied a dampish, dusky, unsunned room, cool, however, to the relief of the fevered muse [of 'Madame de Mauves'], during some very hot weather. The place was so dark that I could see my way to and from my inkstand, but by keeping the door to the court open - thanks to which also the muse, witness of many mild domestic incidents, was distracted and beguiled. (AN 196-97)

Ireland, the home of James's forefathers, provides for verbal comedy by the description of 'a ramshackle inn on the Irish coast, where the table at which I wrote was of an equilibrium so vague that I wonder to-day how any object (i.e. 'The Chaperon'] constructed on it should stand so firm,' This is rounded off with the poetical allusion to the memory of 'The strange sad charm of the tearful Irrsh light' (AN 138).

The London memories, naturally, contain the largest store of James's working-place memories of impressions. On London he is inexhaustible - confused, charmed, stern, ironic and in full pos- 
session. As 'the student of great cities ... the most beset of critics ... the great grey Babylon' with its profusion of 'mysteries (dense categories of dark arcana)' would offer 'the pedestrian prowler ... many a ripe round fruit of perambulation.' A Hyacinth Robinson, for example, who 'sprang up ... out of the London pavement' as a reward 'from the habit and the interest of walking the streets,' and who provided James with the hero of The Princess Casamassima. Such was often the case, 'especially during the younger the initiatory time, the fresh, the sharply apprehensive months or years, more or less numerous':

To haunt the great city and by his habit to penetrate it, imaginatively, in as many places as possible-that was to be informed, that was to pull wires, that was to open doors, that positively was to groan at times under the weight of one's accumulations. 8

'The big human rumble of Picadilly' reminds young James of the characters of Thackeray' while he 'was to find fifty other London neigbourhoods speaking ... almost only with the voice, the thousand voices of Dickens' (AN 212). Summing up pictorially how London appeared to him as a working-place, James uses the terminology of the theatre,

A 'great house', forming the southwest corner of Picadilly and with its long and practically featureless side, continued by the high wall of its ample court, opposite my open-eyed windows, gloomed, in dusky brick, as the extent of my view, but with a vast convenient neutrality which I found, soon enough, protective and not inquisitive, so that whatever there was of my sedentary life and regular habits took a sort of local wealth of colour from the special greyish-brown tone of the surface always before me. This surface hung there like the most voluminous curtain-it masked the very stage of the great theatre of the town. To sit for certain hours at one's desk before it was somehow to occupy in the most suitable way in the world the proportionately ample interest in the mightiest of dramas. When I went out it was as if the curtain rose; so that, to repeat, I think of my tolerably copious artistry of that time as all the fruits of the inter-acts, with the curtain more or less quietly down and with the tuning of fiddles and only the vague rumble of shifted scenery playing round it and through it. (AN 212)

'Out' James did go, to roam the streets, to sit on park-benches or in 'penny-chairs' - from which he watched the figure of 'Owen Wingrave' grow - for dinners in private homes or at his clubs and on week-end visits to the great country houses. During the winter of 1879 he 'dined out 107 times,' he proudly informs Grace Norton ${ }^{\mathrm{g}}$. We find him at dinner tables, in the literary salons or comfortably relaxed before crackling hall-fires eagerly listening-whence he 
hurries home to jot down impressions and anecdotal ideas, garnered during convivial conversation, in his Notebooks as potential germs and material for stories and tales.

James deals rather scantily in the Prefaces with America as a working place since so comparatively few of his NYE-works were done there and because he found 'Europe so constantly in requisition as the more salient American stage' (AN 28). The American memories, such as they are, are limited to New York and Washington, D.C. while Boston and Cambridge come in for a more extensive treatment in the Notebooks. New York again limits itself to

the very moderate altitude of Twenty-Fifth Street ... with the music-masters and French pastry-cooks, the ladies and children, immensely present and immensely numerous these, but testifying with a collective voice to the extraordinary absence ... of a serious male interest.

The male interest, which flourished in the world 'down-town,' was almost exclusively devoted to 'the huge organised mystery of the consummately, the supremely applied money-passion' (AN 274), and thus incomprehensible to James, belonging as he did to a family who 'were never in a single case ... for two generations, guilty of a stroke of business.' 10 Given his interest and bias as a writer, New York would remain to James for all its noisy bigness 'one of the very least of Capitals' (AN 273).

The Prefaces also constitute an autobiography of a writer's spiritual, moral and artistic life of the rarest kind. As James sums it up towards the end of the XVIIIth and last Preface, his farewell lecture, as it were,

What has the affair been at the worst, I am most moved to ask, but an earnest invitation to the reader to dream again in my company and in the interest of his own larger absorption of my sense? ... a sense for ever so many more of the shining silver fish afloat in the deep sea of one's endeavour than the net of widest casting could pretend to gather in; an author's common courtesy dictating thus the best common course for making that sense contagious-It all comes back to that, to my and your 'fun'-if we all but allow the term its full extension.

One may indeed make the point that in no other of his copious writing does James so freely give of his most intimate self - even to the point of giving himself away on occasions - as he does in his Prefaces.

The above pages cover, more or less, the straight part of autobiography in the Prefaces except for the occasional and somewhat casual references James makes to encounters with and lessons 
learned from famous Brothers-in-Art. When he alludes to them it is for a particular purpose. No lecturer can hold the attention of and succeed in persuading any at all critically alert audience who is not able to convince his listeners of his being an authority on his chosen subject. One way of gaining confidence and credulity on this score, is for him to quote the views of other recognized and respected practitioners in the field and then, when occasion allows, to take issue with them and prove them wrong. James does this repeatedly whenever literary practices seem to war against basic artistic principles. In this he is no respecter of persons or reputations.

Speaking of the need to impute to major characters also in hisstorical fiction some amount of demonstrable intelligence or consciousness, i.e. the capacity to feel about what is happening to them, James takes one of Walter Scott's heroes, Edward of Ravenswood in The Bride of Lammermoor, to task because he

has a black cloak and hat and feathers more than he has a mind; just as Hamlet while equally sabled and draped and plumed, while at least equally romantic has yet a mind still more than he has a costume. ... Fielding's hero in Tom Jones ... hasn't a grain of imagination ... [but] He has so much 'life' that it amounts, for the effect of comedy and the application of satire, almost to his having a mind; that is to his having reactions and a full consciousness; besides which his author-he handsomely possessed of a mind-has such an amplitude of reflection for him and round him that we see him through the mellow air of Fielding's fine old moralism, fine old humour and fine old style, which somehow really enlarge, make every one and every thing important. (AN 68)

James's most notorious and controversial pronouncement was made in defense of his insistence that any representational art must obey the compositional law of what he calls 'a deep-breathing economy and organic form' which proscribes 'waste' which is again 'only life sacrificed.' On these grounds he doesn't hesitate in labeling Tolstoi's Peace and War (sic!) together with Dumas' Les Trois Mousquestaires and Thackeray's The Newcomes in spite of all the 'life' they may contain, 'large loose baggy monsters with their queer elements of the accidental and the arbitrary ... (AN 84). This, certainly, is one of the instances when one feels inclined to share T.S. Eliot's view that 'James was emphatically not a successful literary critic.' ${ }^{11}$ Also, one may add, he had little stomach for the more broadly epic mode of narration.

Critical comments on and disagreement with literary theories and practices are found scattered throughout the Prefaces. Edgar 
Allan Poe's Arthur Gordon Pym comes in for a drubbing in connection with the question of how best to deal with the horror or ghost story (AN 256-257) while contemporary English and American prose fiction as well as continental modern drama are given rather short shrift (AN 114; 210; 332). That also regularly happens when James touches upon the phenomenon of the practicing and popularity of the humorous and local color stories - presumably including those of Mark Twain and Bret Harte. Never is he more scathingly scornful than in his diatribes against the literary use of what he considers degenerated and polluted dialect and slang which he stigmatizes as

the riot of the vulgar tongue. ... Grand generalized continental riot or particular pedantic, particular discriminated and 'sectional' and selfconscious riotwhich was to feel the thick breath, to catch the ugly snarl. ... the smartness of echoes and the taint of slang. The thousands of celebrated productions raised their monument to the bastard vernacular of communities disinherited of the felt difference between the speech of the soil and the speech of the newspaper. (AN 279)

Nor will any other topic get James's polemical hackles so ferociously and amusingly up as when he talks of the 'newspaperisation' of culture in general and of literature in particular. It is thus no accident that he chose for one of his two lecture topics during his American tour of 1904-05 'The Question of Our Speech.' Addressing audiences of college undergraduates, 'dear old, good, innocent Harry,' proved, to the great surprise of his widely famed lecturing brother William, a big success among the young people.

The power of persuasion with which James presents his argument to promote his artistic convictions and unconventional practice, derives primarily from the nature and character of his rhetoric. The tone of his address, besides that of intimacy, runs the whole scale from burlesque humor to high seriousness, while his expository method is both analytic and dramatic but never 'pedagogic' in the narrow sense of being didactic. In his style we discover a number of characteristically rhetorical and poetic devices such as the rhythmically balanced sentences, the catalog, the deftly varied repetitions and the subtle changes of emphasis. Above all does James make an extravagantly extensive use of metaphor both in the form of similes and as expanded figures of speech so characteristic of his 'later manner.' Also, it is a style ruled by the comic spirit with its verbal felicities, its unabashed joy in playing with and upon 
words, its love of the shocking, ambushing effect of expertly deployed incongruities.

James's fondness for verbal fun-making is in evidence throughout the Prefaces but as often as not the joke is engagingly on himself. For example, when he alludes to the sad fact-as he somewhat exaggeratedly presents it -of his being unpublished, unsold and unread, he will treat the circumstance with a stiff-upper-lipped wry humor, as when he tells of the publishing history of 'The Story In It':

It still haunted, a graceless beggar, for $\boldsymbol{a}$ couple of years, the cold avenues of publicity; till finally an old acquaintance, about to 'start a magazine', begged it in turn of me and published it (1903) at no cost to himself but the cost of his confidence, in that first number which was in the event, if I mistake not, to prove only one of a pair. I like perhaps 'morbidly' to think that the Story in it may have been more than the magazine could carry. (AN 245)

From the composition of such a passage one suspects the author to have expected at least an audible titter from the audience of his fancied fans.

The late Professor P. H. Lowrey, in an unpublished thesis ('Figures of Speech in Henry James's Prefaces,' The University of Chicago, 1948), counted an average of about three similes per page in Blackmur's edition of the Prefaces. This is a remarkable density even when compared to the later works in the NYE where Robert L. Gale, in The Caught Image (University of Carolina, 1946), finds roughly one image per page, clearly indicating the nature of the prefatorial style. The imagery in the Prefaces serves to vivify the descriptions of various artistic and technical problems involved in the composition of James's fictional work. It is also wonderfully expressive of the author's close and concerned relationship with his stories and characters from their very inception to their full fruition. The metaphorical vocabulary draws upon various terminologies covering the whole spectrum of human activities in the world of arts and crafts and trades and in that of numerous other occupations and professions in which the author fancies himself as being engaged. The roles he assigns to himself range from that of a chef de cuisine or a pastry-cook through that of a weaver or embroiderer to that of a daring adventurer or explorer; James loves to play the architect or the master-builder, the engineer of imposing and ingenious compositional structures as well as the alchemist, magician or conjurer who by sleights-of-hand or his 
special sorcerer's brew is capable $\mathbf{f}$ creating the most wondrous, mysterious and spectacular effects.

James's method of telling 'the story of the stories,' his account of the creative artistic process of execution, lends to the Prefaces through the imagery of the exposition both a pictorial and dramatic value which greatly enhances the pleasure one gets from reading the admittedly complex material. It is a thrilling performance and a unique experience.

Looking at the artist as a young man, James takes the seriocomic view of the writer as a rash adventurer, the explorer and navigator dangerously at sea with his cargo of 'subjects.' The emphasis is on the pathetic failures of 'earnest, baffled intention' caused by the 'scant experience' of the fledgling author who, however, is always blissfully and innocently hopeful of success despite the terrors accompanying the difficulties of execution. Triumph is constantly in the air, 'the blue southern sea seemed to spread immediately before me and the breath of the spice-islands to be already in the breeze' (AN 4). But disaster invariably seems to loom ahead. There is, for instance, the near-fatal mismanagement of the time-scheme in Roderick Hudson which 'just fails to wreck it' (AN 12). There is the matter, again, of The American, flying the flag of Realism but where its author discovers that he has 'been plotting arch-romance without knowing it' (AN 25).

I ask myself indeed, if, possibly, recognizing after I was launched the danger of an inordinate leak-since the ship has truly a hole in its side more than sufficient to have sunk it-I may not have managed, as a counsel of mere despair, to stop my ears against the noise of waters and pretend to myself I was afloat; being indubitably, in any case, at sea, with no harbour of refuge till the end of my serial voyage. (AN 21)

Then, with a characteristic volte-face of metaphor, James rounds it humorously off, comparing himself to the ostrich in danger, ' $\mathrm{I}$. . . must have buried my head in the sand and there found beatitude' (ANibid).

James can't bear to concede defeat on behalf of any one work selected for inclusion in the New York Edition. It was bad enough to have had to leave out The Bostonians as well as several worthy members of his short-story family,

These repudiated members, some of them, for that matter, well-nourished and substantial presences enough, with their compromising rustiness plausibly, almost touchingly dissimulated, I fondly figure as standing wistful but excluded, 
after the fashion of the outer fringe of the connected whom there are not carriages enough to convey from the church - whether (for we have our choice of similes) to the weddingfeast or to the interment! (AN 177-178)

Thus, then, we watch with suspense and amusement, in the Prefaces, the heroic figure of Henry James riding his one-man posse to the rescue, in the neck of time, of his precariously placed 'children of fancy' whom he always seems able to save at the very last moment; Roderick Hudson through the technical expedient of having his story lodged in the sufficiently observant consciousness of his friend Rowland Mallet. In the case of The American, swinging freely in the thin air of the romantic experience, we find James dizzily 'clinging to my hero as to a tall, protective, good-natured elder brother in a rough place' (AN 39). But as the artist matures and gains greater expertness it is he himself who plays the fatherly protector to his 'children of fancy,' ever watching and fussing over them with a fond albeit critical eye. They, on their side, repay him by always being loyally ready to save him from a tight spot, and James will frequently quote them at length as speaking to him in human voices about their assigned roles in his stories.

Repeatedly stressing his role of being the literary historian of his work, James is constantly fascinated by the mystery of story origins, whence the germ came and how and why it sprouted and grew into full bloom under his patient care and endeavour,

Not that I quite know indeed what situations the seeking fabulist does 'find'; he seeks them enough assuredly, but his discoveries are, like those of the navigator, the chemist, biologist, scarce more than alert recognitions. He comes upon the interesting thing as Columbus came upon the isle of San Salvador, because he had moved in the right direction for it. (AN 159)

James seems here to have metaphorically forgotten that Columbus thought he was moving in the direction of India, just as James, when writing The American mistakenly thought he was sailing the waters of Realism. Well, there are other instances in the Prefaces where the figures of speech do not always add up to the correct sum total of literal facts.

In the Preface to 'The Aspern Papers' James refers to

that old law which somehow always makes the minimum of valid suggestion serve the man of imagination better than the maximum. This historian, essentially, wants more documents than he can really use; the dramatist only wants more liberties than he can really take. (AN 161-162) 
In 'The Aspern Papers' James's interest and problem were to make his fictional hero Jeffrey Aspern-suggested to him by a Byron and Shelley associated anecdote-independently representative of a felt 'palpable imaginable visitable past' (AN 164), while its companion piece, the celebrated 'The Turn of the Screw,' had 'the immense merit of allowing the imagination absolute freedom of hand' (An 170), since the germ of its origin was so slight. In connection with the story of 'The Liar,' James describes his intimately felt relation to his works in sexual-biological terms, this story having,

when its hour came, quite especially confirmed to that custom of shooting straight from the planted seed, of responding at once to the touched spring, of which my fond appeal here to 'origins' and evolutions so depicts the sway. When it shall come to fitting, historically, anything like all my children of fancy with their pair of progenitors, and all my reproductive unions with their inevitable fruit, I shall seem to offer my backward consciousness in the image of a shell charged and recharged by the Fates with some patent and infallible explosive. (AN 178)

We are here very far from the terminology of the puppet-show manipulator that James makes use of in other instances, and such changes in tone, attitude and imagery frequently occur. Where James is driven to seek for his 'origins' in the depths of his private, innermost, moral Self, he often becomes evasive and ambiguous or he will simply and flatly refuse to commit himself. The Preface to the volume of artist stories, 'The Lesson of the Master' (AN 217-231), provides illustrative examples.

Recommending the nouvelle as the ideal vehicle for the handling of 'material for any picture of personal states ... specifically complicated' as they are in the artist stories, James freely admits that this material 'will have been drawn preponderantly from the depths of the designer's own mind ... fathered but on his own intimate experience.' The artist characters, his 'super-subtle fry,' James insists, 'have their justification in the ironic spirit,' the irony being that if we don't find their counterparts in real life, so much the worse for that life. This also goes for the tantalizing and teasingly enigmatic 'fable for critics,' 'The Figure in the Carpet,' the 'meaning' of which has puzzled readers and critics as much as it does the story-characters themselves. It is a crowning example of the prankish pleasure James inveterately takes in pulling legs -as he also does, though to a chillingly different effect, in his ghost story, 'The Turn of the Screw' Preface where he waxes positively complaisant: 
As for the all-ingenious 'Figure in the Carpet,' let me perhaps a little pusillanimously conclude, nothing would induce me to come into close quarters with you on the correspondences of this anecdote. ... All I can on this point say is that if ever I was aware of ground and matter for a significant fable, I was aware of them in this connexion. (AN 224-225)

Finally, as to the especially autobiographical provenance of his artist stories, James concludes,

I shouldn't therefore probably have accumulated these illustrations without the sense of something interchangeable, or perhaps almost even indistinguishable, between my own general adventure and the more or less lively illustration into which I was to find this experiment so repeatedly to flower. Let it pass that if I am so oddly unable to say here, at any point, 'what gave me my idea,' I must just a trifle freely have helped myself to it from hidden stores. (AN 225)

Noting the development of his artistic expertise as the result of continued application and the growth of imagination through accumulated experience, James's tone of voice takes on another quality which becomes more and more pronounced as he progresses in time from, say, The Portrait $₫$ a Lady and on. He may still strike the apologetic note when commenting on earlier works as he does when dealing with his handling of the 'international theme' of the Daisy Miller days, but the imagery of danger and terror and frustration is displaced by that of joy and pride and banter about achieved results. The humor is retained all through but now he speaks in a more and more authoritative voice. His viewing with alarm gives way to his pointing with pride at, say, the expert dramatic handling and scenic consistency of The Tragic Muse or, more particularly, of The Awkward Age which, on reperusal, makes him almost ecstatic when he experiences how the flush of life reappears' (AN 99). He finds it 'triumphantly scientific ... with every symptom of soundness, an insolence of health and joy' (AN 117).

These effects of 'associational magic' which James discovers in What Maisie Knew, come out in 'the scene ... vivid, special, wrought hard, to the hardness of the unforgettable' (AN 147-148) and with Maisie and its companion pieces, 'In the Cage' and 'The Pupil' he revels in the observation of how consistently they obey the scenic law that 'To read them over has been to find them on this ground never at fault' (AN 157). 'The Reverberator' he finds to be a prime example of a 'jeu d'esprit.' He thinks of it as an exemplary anecdote, and at the same time ... a little rounded drama' 
(AN 180), while 'Greville Fane' comes close to being 'a minor miracle of foreshortening' (AN 234).

With the dramatist James shares what he calls 'his technical amusement' and never is the humor of his imagery more infectious than when he employs it to illustrate some contributive or attendant technical aspects of composition, as, for instance, when he speaks of romantic and historical sites as writing locations,

such as the land of Italy abounds in [which] offer the artist a questionable aid to concentration when they themselves are not to be the subject of it. They are too rich in their own life and too charged with their own meaning merely to help him out with a lame phrase; they draw [the writer] away from his small question to their own greater ones; so that, after a little, he feels, while thus yearning towards them in his difficulty, as if he were seeking an army of glorious veterans to help him arrest a peddler who has given him the wrong change. (AN 40-41)

Talking about the ficelles, James explains how they are figures and not real characters since they belong less to the action subject than to the treatment, and thus

they may run beside the coach 'for all they are worth,' they may cling to It till they are out of breath ... but neither [i.e. Henriette Stackpole in The Portrait of a Lady and Maria Gostrey in The Ambassadors], all the while, so much as gets her foot on the step, neither ceases for a moment to tread the dusty road. Put it even that they are like the fishwives who helped to bring back to Paris from Versailles, on that most ominous day of the first half of the French Revolution, the carriage of the royal family. (AN 55)

On the vexing problem of 'misplaced middles,' of not getting 'the organic center ... into proper position,' which James deems to be one of his major failings in his larger compositions - although, of course, mainly and rather successfully dissimulated -he amusingly observes,

Time after time, then, has the precious waistband or girdle, studded and buckled and placed for brave outward show, practically worked itself, and in spite of desperate remonstrance, or in other words essential counterplotting, to a point perilously near the knees-perilously I mean for the freedom of these parts. (AN 85-86)

It is James's metaphorical flights into such incongruities that provide for so much of that humor and fun which make the pedagogical instruction of the Prefaces so entertainingly illuminating. They are the Master's friendly raps of the ferule on the knuckles of our suspected inattention. 
Taking for granted that we have accepted our assigned roles as willing learners, James strives indefatigably to bring home his main points even to the dullest of his students. His main concern is to demonstrate how an artist lives in his works and how that life is an adventure in experience fraught with danger and difficulty but also filled with joy and bliss,

a human, a 'personal' adventure is no a priori, no positive and absolute and inelastic thing, but just a matter of relation and appreciation-a name we conveniently give, after the fact, to any passage, any situation, that has added the sharp taste of uncertainty to a quickened sense of life. (AN 286)

An adventure is to experience the extraordinary which 'is most extraordinary in that it happens to you and me, and it's of value (of value for others) but so far as visibly brought home to us' (AN 257). Hence

the author's irrepressible and insatiable, his extravagant and immoral, interest in personal character and in the 'nature' of a mind, of almost any mind the heaving little sea of his subject may cast up ... (AN 156).

It is by these criteria, by the 'ideal beauty of subject' since there are 'degrees of merit in subjects' even while the artist is left completely free to choose among them, that James singles out his favorites among his own works, The Portrait o a Lady where in Isabel Archer he 'might show what an exciting inward life may do for the person leading it' (AN 56) and The Ambassadors, where in Lambert Strether he had found 'a hero so mature, who would give me more to bite into since it is only into thickened motives and accumulated character, I think, that the painter of life bites more than a little' (AN 310).

Casting himself in the role of magician, James becomes more explicit about what is, subconsciously perhaps, the key to the understanding of what constitutes the artist's primary motive and ambition: His lust for power, an almost Faustian obsession,

he alone has the secret of the particular case ... the art of guiding it with consequent authority-since this sense of 'authority' is for the master-builder the treasure of treasures, or at least the joy of joys-[which] renews in the modern alchemist something of the old dream of the secret of life. (AN 123)

The artist works and must work under the illusion of artistic freedom but Art is definitely not Life. True enough, 'it plucks its material ... in the garden of life - which material elsewhere grown is stale and uneatable' (AN 312), but 
We can surely account for nothing in the novelist's work that hasn't passed through the crucible of his imagination, hasn't, in that perpetual simmering cauldron of his intellectual pot au feu, been reduced to savoury fusion. (AN 230)

The artist's life, however, resides in his 'doing,' in his creation of art, in the act itself. That is the raison d'être of his metier and all the romance of his career on the strength of which he lays claim to the title of Poet.

In the last passages of the XVIIIth and final Preface, where the style attains the pitch of passionate confession, James defines his artist's creed as the 'Religion of Doing.' In this he is closely akin to the representative men of the 'Old America,' to Emerson and Thoreau, to Melville, Poe and Whitman-however mixed a chorus their voices may strike one's ear as sounding. For all his cosmopolitanism and sophistication, whether he is using the tools of romanticism or realism, James is still unmistakably an American of solid puritan stock, singing the poet's song of the bliss and bane of the human condition. His Prefaces are thus the final demonstration of how secure is his place among those artists who shine by their proven example and who need no fixed labels for identification.

\section{N O T E S}

1 The Letters of Henry James, ed. Percy Lubbock, vol. I (NewYork, 1920), 135; later referred to as Letters $1 / 11$.

2 Letters, II, 70.

3 Letters, II, 99.

4 Further referencesto the Prefaces will be to The Art of the Novel, ed. and with Introduction by R. P. Blackmur (NewYork, 1934; 1947); abbrev. AN.

5 The Notebooks of Henry James, eds. F. O. Matthiessen and Kenneth B. Mur* dock, with Introduction and Annotations (NewYork, 1947); later referred to as NB.

6 Letters, II, 70.

7 Partial Portraits, (London and New York, 1888), pp. 375-376.

8 All the above London quotations have been culled from the Preface to The Princess Casamassima (AN, 59,78).

9 Letters. I, 96.

10 Notes of a Son and Brother by Henry James (New York, 1914), p. 190.

11 The Qestion of Henry James, F. W. Dupee (NewYork, 1945), p. 109. 